\title{
On historical earthquakes in Switzerland: summary of compilations and investigations
}

\author{
Dieter Mayer-Rosa $\left({ }^{1}\right)$ and Gabriela Schwarz-Zanetti $\left({ }^{2}\right)$ \\ (') Schwandenholz 260, CH-8046 Zürich, Switzerland \\ ${ }^{(2)}$ Swiss Seismological Service, ETH-Honggerberg, Zürich, Switzerland
}

«It is the investigation of the properties and forces of na-
ture, / which was all the time one of the most pleasant and
useful efforts».
J.J. Scheuchzer, Historia Naturalis (1716)

Abstract

Studies of historical earthquakes in Switzerland are contained in monographs, chronological collections of effects and parametric catalogues. The systematic collection of macroseismic material started with the creation of the Swiss Seismological Commission in 1878. All parametric catalogues since 1975 have been prepared for seismic hazard assessment. The most up-to-date investigation of macroseismic data and compilation into a catalogue (ECOS) was made in the 2002 in context of the re-assessment of seismic hazard for nuclear sites.

Key words Switzerland - historical earthquakes ECOS - seismic hazard

\section{Introduction}

Descriptions of historical earthquakes in Switzerland can be divided up into three categories: i) Monographs on single prominent earthquakes by one author (e.g., Heusser, 1856), ii) Chronological collections of earthquakes and observed phenomena (e.g., Volger 1857-1858), iii) Catalogues with source parameters deduced from the descriptive information (e.g., MECOS, 1999). The third category, especially after 1975, is almost exclusively prepared for input to seismic hazard assessment.

Mailing address: Dr. Dieter Mayer-Rosa, Schwandenholz 260, CH-8046 Zürich, Switzerland; e-mail: dmrosa1@bluewin.ch
Their contents and quality are therefore specially geared to the required input and the desired output of such projects.

Certain events in history have often initiated or intensified the investigation of historical earthquakes in Switzerland. Such an effect certainly occurred e.g. after the destructive Lisbon and Valais earthquakes in 1755, the establishment of the Swiss Earthquake Commission (SEC) in 1878 , or even by demand of the regulatory body for improved seismic hazard assessments, as in 1974 and 1998 for nuclear installations. The introduction of Forel's intensity scale in 1880, or the installation and continuous operation of the first seismographs between 1913-1922 and the introduction of efficient computer-based networks and data evaluation from 1970 also significantly accelerated the investigation of earthquakes.

The foundation of the Swiss Earthquake Commission in 1878 caused probably the most remarkable progress in the history of earth- 
quake investigation in Switzerland (Früh, 1911). The SEC was active until 1914, when its duties officially were taken over by the Swiss Meteorological Central Institute (Schweiz. Meteorologische Anstalt), and funded by the Swiss Government. This transition also marks the onset of instrumental observations, another landmark in the history of seismology in Switzerland. For completeness it should be mentioned here that the Earthquake Service was transferred again in 1956 to the Swiss Institute of Technology (ETH-Zürich).

On the other hand, the investigation of historical earthquakes as such was never regarded as a prime task in Swiss Geosciences after WW II. It was usually left to individuals with a strong motivation to work on this «side track of real science».

This summary concentrates on the enumeration of significant works completed in different epochs in Switzerland and, if appropriate, de- scribes the connected projects. Historical aspects and methods are also briefly touched upon.

\section{The pre-1878 period}

Lycosthenes (1557) wrote one of the earliest chronicles on earthquakes, mixed with all sorts of other noteworthy observations in nature, as was usual at that time. Scheuchzer (1716-1718), the famous Swiss scientist (medical doctor and mathematician) published his books on historical earthquakes, which are «felt in Switzerland from time to time» in 1706 and following years. He also identified active zones in Northern Switzerland, e.g. the border area to Germany, the region of Basel and the Canton Glarus. A rich compilation of historical earthquakes is found in the books of Bertrand $(1756,1757)$ with special focus on the 1755 Visp (Valais) earthquake.

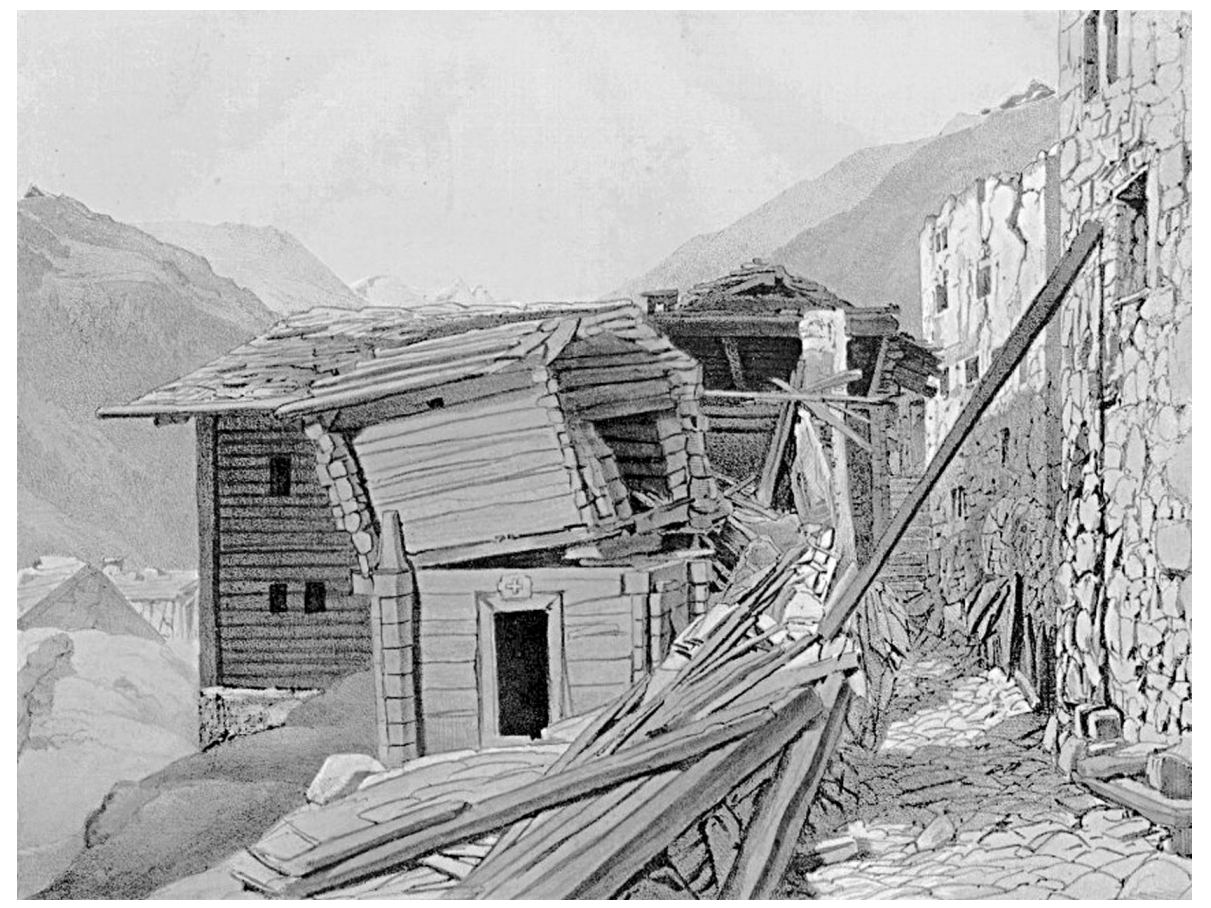

Fig. 1. Realistic drawing of an unknown artist from a typical building (Mazot) near Stalden/VS, damaged by the Earthquake of 25 July 1855 (in: Heusser, 1856). 
Heusser (1856) published the first objective description on the Visp 1855 earthquake. He also included personal observations in the epicentral area together with four realistic drawings of earthquake scenes, created on the spot by an unknown artist (fig. 1). These drawings can be seen as direct precursors of photographic pictures taken from the second half of the 19 th century onwards. They are certainly realistic and of interest with respect to the question of whether artistic depictions can help to evaluate the severity of historical events.

Volger (1857-1858) produced an impressive compilation on historical earthquakes for Switzerland between 800 and 1855 . The second volume of three contains a large collection of felt earthquakes with detailed descriptions of locations with observed phenomena and - most important - with references to many documents used. This must be considered the first compilation in Switzerland, which met to a certain extent the historical-scientific requirements on completeness and objectivity - a milestone for its time. However, he made no attempt to classify the observations according to any scale. In the third part of this work Volger describes in detail the effects of the prominent earthquake activity of 1855 in the Visp Valley in the Canton of Valais. He used statistical figures to describe these earthquakes, their geographical distribution and correlation with meteorological observations. For the cartographic presentation of the macroseismic observations of the strongest four shocks in 1855 he developed his own 7-graded scale, which was never used after that by anybody else. Another noteworthy manuscript of Mayer (ca. 1860) lists earthquakes between 1350 and 1859 in chronological order.

\section{The 1878-1975 period}

The Swiss Earthquake Commission, founded in 1878, was the first commission of this kind in the world, before Italy in 1879 and Japan in 1880 followed with similar organisations. This fact probably caused the most drastic change in the style of earthquake investigation in Switzerland in this century. Macroseismic data and related documents hereafter were systematically collected and archived with rigorous standards. From 1881 the commission published 33 annual bulletins (Jahresberichte, 1881-1914) until 1914 within the Annals of the Swiss Meteorological Central Agency (SMA) in Zürich. The public was requested to send earthquake observations on a form with prepared questions in German, French and Italian.

Soon after the establishment of the Commission, Forel created his 10-graded macroseismic scale and in 1882, the updated «Swiss-Italian» Rossi-Forel intensity scale followed. It became very popular among seismologists and the media and was the preferred scale until 1964, when the MSK-64 scale was introduced. It is noteworthy that even 20 years later Candreia (1905), a librarian, totally ignored the new macroseismic scales in his chronology of earthquakes between 823 and 1897 in the Canton Graubünden. On the other hand, he already used a historicocritical investigation of sources, at least for a part of his work. The period 1856-1879, just before the creation of the Commission, was covered by Wanner (1932) in his earthquake catalogue for Switzerland.

The Swiss Seismological Service was finally created in 1913 within the SMA, and the idea of installing a new seismograph with 21 tons mass was realized in 1922 in Zürich (Station ZUR). This instrument, in conjunction with other similar instruments in Neuchâtel and Basel, initiated another new era of seismology in Switzerland. The systematic collection of macroseismic data did not come to a halt; it was now seen as complementary to regular and continuous instrumental recordings.

In 1956, the Swiss Seismological Service was integrated in the new Geophysical Institute at the Federal Institute of Technology and issued annual seismological bulletins from 1913 to 1964 with instrumental and macroseismic data (SED, 1913-1964). The isoseismal maps published in the bulletins served as the main databases for the compilation of catalogues, since the original macroseismic data have not been preserved.

The strongest Swiss earthquake in this century occurred on 25th January 1946 near the 
city of Sion (Valais), about $50 \mathrm{~km}$ west of the Visp 1855 activity. It was originally assigned intensity IX (RF-Scale) and caused about 7 Mio Fr damage $\left(\right.$ corresponding to $I_{o}(\mathrm{EMS})=$ VIII and about 80 Mio today's value). More than 500 aftershocks followed the two main shocks on 25 and 30 January. Unfortunately all of the original macroseismic data were lost and only generalized isoseismal maps survived. However, in a re-evaluation of this event many of the macroseismic data points in and around Switzerland could be reconstructed (Schibler, 2000).

An illustrative map of earthquake centres between 1295 and 1971 was created by Pavoni (1977), depicting felt and damaging earthquakes using a simplified scheme of 4 categories for the observed effects.

\section{Recent catalogue studies after 1975}

A comprehensive earthquake catalogue (SCAT, 1975) covering the time period between 1300 and 1974 was compiled for the first probabilistic seismic hazard maps of Switzerland (Saegesser and Mayer-Rosa, 1978). Most earthquake parameters of this catalogue are based on the evaluation of existing descriptive compilations listed in chapters 3 and 4, and complemented by the catalogues of Montandon (1942), Sieberg (1940), Sponheuer (1952) and Karnik (1969-1971). It can be regarded as up-to-date in terms of completeness and macroseismic parameters (MSK-64) for that time. Besides the evaluation of the very heterogeneous material, considerable efforts had to be invested in the conversion of the different scales used in these publications into the MSK-64 scale (Medvedev et al., 1965). It should be mentioned that the original intensity assessment of Montandon was found to be systematically too high by 1-2 degrees in terms of MSK-64/EMS-98 figures. For the first time also a unified uncertainty scheme for all parameters was introduced in the SCAT (1975) catalogue. The works of Sieberg and Sponheuer have been mainly compiled for earthquakes in Germany, which nevertheless was of importance for events near the border having effects in Switzerland.

\subsection{The MECOS earthquake catalogue}

In the early 1990s a revision of the SCAT (1975) catalogue was undertaken. For this purpose about 6000 macroseismic observations have been associated with uncertainty figures, to be used in the construction of attenuation relationships for a new probabilistic seismic hazard study (Rüttener, 1995). In particular, the use of discrete probability distributions to characterise uncertainties was regarded as an important step compared to the former use of normal error distributions. Half-grade intensity values were also eliminated in this way. Source evaluation procedures developed in the EC project RHISE were used for the strongest events (Albini et al., 1989).

The Internet catalogue of 1997, named MECOS (Macroseismic Earthquake Catalogue of Switzerland), represented a part of the Rüttener catalogue containing all earthquakes with intensity $\mathrm{V}$ and higher. Epicentral (MSK-64) intensity was used as main source parameter for the earthquake size. No attempt was made to convert intensity into a homogeneous magnitude $M$ of some kind. However, for internal use, a simplified conversion of the form $M=0.5 I_{o}+1.5$ was taken when (approximated) magnitude figures of historical events were requested. This corresponds to the well-known relationship by Karnik (1969-1971) for Europe and $10 \mathrm{~km}$ average depth of focus.

A joint seismic hazard study for the German speaking countries Germany, Austria and Switzerland (DACH-Project) was carried out between 1996 and 1998 (Grünthal and MayerRosa, 1998). For this study a homogenisation of national earthquake catalogues was required, especially for major earthquakes in the border areas between these countries. The hazard map is presented in terms of (EMS-98) intensities for 475 years average recurrence time. The common earthquake catalogue includes many events which had to be re-assessed in terms of intensity and location. The GeoForschungsZentrum in Potsdam/Germany hosts the DACH catalogue.

\subsection{The ECOS earthquake catalogue}

In the context of a new hazard assessment for nuclear sites (PEGASOS) and new seismic 
hazard maps for zoning purposes (Swiss Building Codes 261), the Swiss Seismological Service undertook a substantial historico-critical and seismological revision of the total macroseismic database. A new earthquake catalogue (ECOS, 2002a) was established by fusion of all historical and instrumental catalogues relevant for the larger Swiss region.

The revision took place in several parts: i) the early period up to 1878 , ii) the period 1879 -1963 (Wössner 2001) and iii) from 1964 up to today. A number of publications by the ETH group, starting in Eclogae Geologicae Helvetiae (vol. 3, 2003), will cover the investigations of the $1021,1295,1584,1601$, 1755, 1796, 1855 and 1946 events. Figure 2 shows for reference purposes the largest earthquakes $\left(I_{o} \geq\right.$ VII or $\left.M_{w} \geq 5\right)$ of the catalogue. This map is also representative for the catalogues mentioned in this section, with exemption of the event in 1524, which was added only recently. It is interesting to note that the 1117 Verona earthquake had damaging effects in Switzerland.

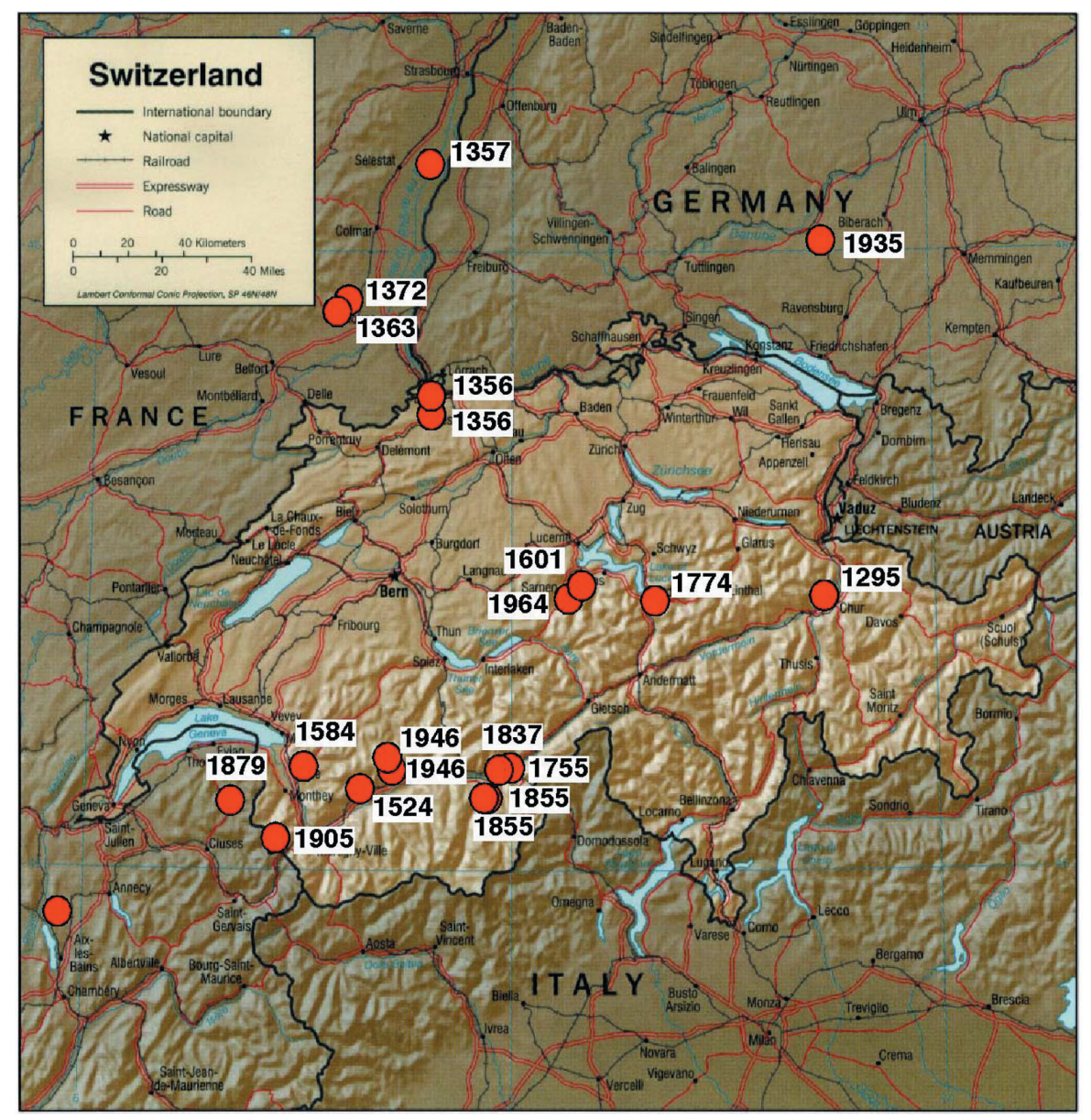

Fig. 2. Epicenter map of Swiss earthquakes 1200-2000 with $I_{o} \geq$ VII (EMS-98) or $M_{w} \geq 5$, including bordering areas. 
The new ECOS catalogue includes i) Events located within or outside Switzerland, which produced significant effects $(I \geq \mathrm{V})$ in Switzerland. They have been substantially re-evaluated with respect to size and macroseismic effects. ii) Earthquakes $\left(I_{o} \leq \mathrm{VI}\right)$ located within a distance of 200-300 km to the Swiss borders, for which the original parameters have been adopted from the original catalogues, iii) Earthquakes $\left(I_{o} \leq \mathrm{VI}\right)$ inside Switzerland, in general based on the MECOS catalogue. Prehistoric times could also be considered, thanks to several paleoseismic studies carried out in the northern part of Switzerland (Becker et al., 2000; Meghraoui et al., 2001).

For the definition of the quality and reliability of the macroseismic information, the standards of the European BEECD project (Albini et al., 2000) have been followed where considered appropriate. Also a root classification procedure, introduced in the BEECD project (Albini and Stucchi, 1997), was used in this study for certain events. All intensity points were assessed in - or transformed into - EMS-98 values. Finally, and most important, a homogeneous magnitude $\left(M_{w}\right)$ throughout the catalogue was introduced. Both procedures are described in the downloadable ECOS Report (2002b).

Another finding during the preparation of ECOS was that the generic uncertainties in location are generally larger than previously anticipated. For events with intensity smaller than $\mathrm{V}$ this uncertainty was set to $5-10 \mathrm{~km}$ before $1878,10-20 \mathrm{~km}$ before 1750 and $20-50 \mathrm{~km}$ before 1650. The uncertainties for larger events have been assessed individually from the distribution of maximum observed intensity points.

\section{Historical aspects}

For ECOS, earlier compilations served as guidelines for intensive searches in libraries and archives for primary (eyewitness) sources such as annals, chronicles written by clergy and laymen, private and official documents, newspapers, journals etc. For assessing the reliability of sources, the historico-critical method developed in the 19th century (e.g., Droysen 1857) was employed by the historical research group at the ETH Zürich, referred to as external and internal criticism.

The external criticism defines the author and his background, the place of observation, the date of the event and the context of the writing. This allows qualifying the source as: A - eyewitness; B - very close to the event; $\mathrm{C}$ - uncertain document; $\mathrm{F}$ - fake.

The internal criticism focuses on the description itself. Also aspects of mentality and writing skills are considered here. Crosschecking between different (i.e. at least three) sources was intended for deriving reliable statements, but was not always achievable in Switzerland for the earlier centuries. The goal was to obtain a provable historical minimumstatement. One condition for declaring an $I_{o} \geq$ VI earthquake was the explicit mentioning damage in the primary documents. Otherwise, the contemporary use of the language and religious or scientific/political intentions could lead to considerable misinterpretation.

In Early and High Middle Ages the historical information on earthquakes is generally very poor ( «an earthquake happened on the day of ...»). The first confirmed event in the new ECOS catalogue is one in 849, besides of a rockslide (possible earthquake) in the Wallis in 563. The first event with mentioned damage appeared in 1117 (Verona!). At the end of the 13th century a few annals gave better descriptions, as for example the Annales Colmarienses for the event of 1295 in Churwalden (Graubünden), which - in previous studies always regarded a questionable event - could definitively be located at this place. On the other hand the event 1021 of Basel was confirmed to be a real fake.

In the 14th century, the first town-chronicles appeared in Switzerland giving general descriptions of natural phenomena, probably motivated by a series of disasters in the middle of this century, e.g., the 1348 «Villach» earthquake. The famous 1356 Basel event (MayerRosa and Cadiot, 1979; Wechsler, 1987) is hence described in several chronicles, letters and other documents (e.g., Das rote Buch von Basel, 1357; Die Verweser des Bistums von Konstanz, 1356; Senn von Münsingen, 1362; Closener, 1362; Mueller 1380). For the region 
of Basel the oldest known diary with nature observations started in 1399 (Anonymous, 1399). It contains only two earthquakes besides weather and astronomical observations. In the middle of the 15th century a gap in information exists, probably because of different local war-activities during this time.

In the 16th and 17 th centuries the frequency and quality of information in chronicles, diaries, official registers and in scientific and religious documents increased substantially. But even the most important events of 1584 (11 March, Aigle/VS, $M_{w}=6.4, I_{o}=$ VII) and 1601 (18 September, Unterwalden, $M_{w}=6.3, I_{o}=$ $=$ VII) in this period still show large geographical gaps of the reported places. A damaging earthquake in 1524 (April, Ardon/VS, $M_{w}=6.4$, $I_{o}=$ VIII) was only recently found, probably because it was described only by one (reliable) witness. This also shows the poor database for this time period.

In the first half of the 18th century science in Switzerland was progressing significantly. Many handwritten documents on several topics of natural phenomena such as earthquakes were found. The 1755 Visp earthquake in the Valais attracted particular attention among reporters because of the Lisbon earthquake only one month before. In the second half of the century scientists apparently lost interest in earthquakes. For this time only private documents such as journals, letters, etc. are available. The production of newspapers is only starting in the last part of this period. Appearing in about 1780 a monthly newspaper
(Neue Zürcher Zeitung) frequently reported on earthquakes in Northern Switzerland.

In the 19th century the production of newspapers increased enormously and most information on earthquakes for ECOS is taken from this kind of documents, but also from scientific papers e.g., published by the Naturforschende Gesellschaft Zürich (published from 1746).

For the 20th century three different types of documents were available: newspapers, the annual bulletins of the Swiss earthquake commission (from 1879) and different official questionnaires (Meldekarten) of the SED (since 1964). Existing macroseismic data-files could be crosschecked with foreign databases, especially with respect to major near border earthquakes.

The completeness of events over the centuries is by no means satisfactory (table I), which is true also for the neighbouring countries. It is found that the political situation often is regarded as more important for a chronicler than anyway relatively rare earthquakes (i.e. the French and Swiss revolution at the end of the 18 th century). On the other hand, there were periods of time, when interest in science emerged again, e.g., 1510-1525 or 1650-1750, and for which scientists and chroniclers left rich material. In general, earthquakes were not in a broad focus (for different reasons) in the second half of the 18th century and therefore have been reported rather seldom.

Besides assessing the completeness of a data set by relatively standardized statistical methods, it is also interesting to illuminate this aspect

Table I. Estimated «completeness» of major earthquakes (Intensity $\geq$ VII) in the new ECOS 2002 catalogue from the historian's point of view.

\begin{tabular}{lcl}
\hline \hline \multicolumn{1}{c}{ Century } & Completeness & \multicolumn{1}{c}{ Background situation and comments } \\
\hline Early and High Middle Ages & $5-20 \%$ & $\begin{array}{l}\text { Eyewitness reports are only found in few annals of } \\
\text { monasteries in NE Switzerland. } \\
\text { Interest in science increased in general, first two earth- } \\
\text { quakes with damage descriptions }\end{array}$ \\
12th and 13th & $5-25 \%$ & $\begin{array}{l}\text { Basel 1356-event found widespread public attention; sen- } \\
\text { sitivity of the observers increased in the towns; improved } \\
\text { education; paper mills and printing introduced }\end{array}$ \\
14th and 15th & $25-50 \%$ & $\begin{array}{l}\text { Lack of sources for mountain areas (e.g., Graubünden, } \\
\text { Central Switzerland, Ticino and Valais), where reliable } \\
\text { sources appear only slowly }\end{array}$ \\
\hline 16th and 17th & $50-75 \%$ & \\
\hline
\end{tabular}


from a historian's point of view. However, this method is much more complex, since local historical aspects make this assessment very uncertain for the whole country. The historians of the ECOS group do, therefore, not feel very comfortable with the generalized table I.

Very helpful in the evaluation of sources were the comments of Alexandre (1990), who examined critically the printed primary sources of central European earthquakes, which are believed to be as complete as possible for the time covered between 394-1250.

A special problem was the association of identical events in documents of different cantons, due to the varying calendars used in parallel in Switzerland between the 16th and 19th century. Some catholic cantons had already adopted in 1584 the Gregorian change of 1582, others followed in 1587 (Unterwalden) or 1655 (Valais). The protestant cantons changed much later between 1701 and 1724 and the last one in 1812 (Graubünden). To make it even more complicated for the analyst, private sources changed at will and sometimes without any indication. This obviously led to duplications in earlier catalogues, which could be eliminated in ECOS.

\section{Conclusions}

The investigations of historical earthquakes in Switzerland in the past 25 years were mainly triggered and sponsored by seismic hazard projects. Among them are the requests of regulatory or government bodies to assess the hazard and risk for nuclear installations, hydroelectric plants and zoning in connection with engineering building codes. The expected output of such projects has set the main guidelines for the composition of parameters in the catalogues. Seismic intensity was the primary ground motion mapping parameter for the 1978 seismic hazard project (Saegesser and Mayer-Rosa, 1978). Therefore the main efforts have been spent to produce reliable intensity values in the catalogues and all attenuation relationships were elaborated in this way. For the compilation of the first comprehensive catalogue for the 1978 hazard study only 6 personal months could be invested. The main goal of this hazard study was to obtain for the first time homogeneous and comparable output parameters for all nuclear sites in Switzerland.

With the availability of instrumental data and also the use of sophisticated computer codes in 1995 an update of seismic hazard assessment for 10 selected cities in Switzerland could be made (Rüttener, 1995). The main point in this study was the explicit implementation of uncertainties into probabilistic hazard calculations. The principal output was defined by seismic intensity as primary ground motion. For the re-evaluation of macroseismic data in the respective catalogue (including the production of attenuation relationships for strong earthquakes) about 1 personal year was scheduled. This study showed unexpected large uncertainties in the resulting ground motions, especially for recurrence times larger than 1000 years. It also demonstrated the importance of a careful evaluation of the uncertainties in the basic catalogue data and hence the importance of an intensified and refined investigation of historical earthquake material in general.

The hitherto most sophisticated seismic hazard assessment project (PEGASOS) was started in 2000, initiated by the Swiss Agency for the Safety of Nuclear Installations (HSK). The spectral ground motion accelerations have to be assessed for much larger return periods ( $\geq 1 \mathrm{Mio}$ years) than considered previously. This required a new effort in historical earthquake investigation, which was performed by a specialized group of historians and seismologists at the Swiss Seismological Service (ECOS, 2002b).

Numerous groups and individuals have completed a number of most sophisticated studies of historical earthquakes in Europe in the past two decades. They have brought this field to a very high scientific standard. However, a deficit in some points may still be recognized:

- The full harmonization of historical earthquake data and catalogues across political borders in Europe is not yet achieved.

- The common assessment of intensities through internationally coordinated field observations is still in its infancies, certainly on European level.

- The proper implementation and practical use of common intensity scales (EMS-98) must be enhanced. 
- The unification of methods and procedures used in historical investigations in Europe should be enforced.

The investigation of historical earthquakes deserves to be put on a new level of intensified cooperation in Europe, starting with the joint collection of damage data just after an earthquake up to the final consensus how to use such data for the benefit of the public. The European Seismological Commission provides one very suitable platform for these objectives.

\section{Acknowledgements}

The authors appreciate the fruitful discussions with the other members of the historical earthquake group of the Swiss Seismological Service at the ETH Zürich, and also the permission to include some of their important findings in this summary. The helpful comments of two reviewers are gratefully acknowledged.

\section{REFERENCES}

Albini, P. and M. StucCHI (1997): A Basic European Earthquake Catalogue and a Database for the evaluation of long-term seismicity hazard (BEECD), in Seismic risk in the European Union, edited by A. GHAZI and M. YEROYANNI (Brussel-Luxembourg), vol. 1, 53-77.

Albini, P., E. Chignola, M. Ferrari and M. Stucchi (1989): Revision of the seismicity of North-Western Alps in the first half of the XVIII century. The 1755, December 9, Valais event, Progress Report, pp. 165.

Albini, P., C. Mirto, M. Stucchi and R. TAtevossian (2000): Contribution to the improvement of the supporting dataset of the most significant earthquakes (1000-1899) for the Swiss territory, Rapporto tecnico IRRS-CNR, Milano, pp. 64.

AleXANDRE, P. (1990): Les séismes en Europe occidentale de 394 à 1259. Nouveau catalogue critique, in Sér. Géophys., Observ. R. Belgique (Bruxelles), pp. 267.

ANONYMOUS (1399): Library of the University of Basel, E. VI. 26.

Becker, A., C.A. Davenport, W. Haeberli, C. Burga, R. Perret, A. Flisch and W.A. Keller (2000): The Fulnau landslide and former Lake Seewen in the Northern Swiss Jura Mountains, Eclog. Geol. Helv., 93, 291-305.

BerTRAND, M.E. (1756): Mémoire sur les Tremblements de terre, P.A. Chenebie, Vevey, pp. 218.

Bertrand, M.E. (1757): Mémoires Historiques et Physiques sur les Tremblements de Terre, La Haye, pp. 328

CANDreia, J. (1905): Zur Chronik der Erdbeben in Graubünden bis zum Jahre 1879, Wyss, Bern, pp. 120

Closener, F. (1362): Chronicles of Strasbourg: code his- torique et diplomatique de la ville de Strasbourg, t.1, 155-157, in W. WACKERNAGEL, 1856.

Das rote Buch von Basel (1856) (The red Book of Basel) (1357). Handwriting of the town archive of Basel, in W. WACKERNAGEL, 1856.

Die Verweser des Bistums von Konstanz (1356): Document at the State Archives in Basel, in W. WACKERNAGEL, 1856.

Droysen, J.G. (1857): Historik. Rekonstruktion der ersten vollständigen Fassung der Vorlesungen, edited by P. LEYH, 1977, Stuttgart.

ECOS (2002a): Earthquake Catalogue of Switzerland (on line: http://histserver.ethz.ch).

ECOS (2002b): ECOS Report to PEGASOS, Version 31 march 2002 (SED, Zürich), (on line: http://histserver. ethz.ch/download/ECOS.pdf).

FRÜH, J. (1911): Ueber die 30-jährige Tätigkeit der Schweiz. Erdbebenkommission. Verh. der Schweiz. Naturforschenden Gesellschaft in Solothurn 1911 (Genève, Soc. Gén. d'Imprimerie), pp. 24.

GrüNTHAL, G. and D. MAYER-RosA (1998): Einheitliche Erdbebengefährdungskarte für Deutschland, Österreich und die Schweiz, Report, Schweizerischer Pool für Erdbebendeckung, Bern.

Heusser, Chr. (1856): Das Erdbeben im Vispertal vom Jahr 1855, Orell - Füssli, Zürich.

Jahresberichte der Schweiz. Erdbebenkommission (18811914): Archives of the Swiss Seismological Service (ETH-Zürich).

KARNIK, V. (1969-1971): Seismicity of the European Area. Reidel, Part I (D. Reidel Pubbl. Comp., Dordrecht, Holland), pp. 220; Part II (D. Reidel Pubbl. Comp., Dordrecht, Holland), pp. 218.

Lycosthenes (Wolfharth), C. (1557): Prodigiorum ac ostentorum chronicon, XIII, Basel, pp. 672.

MAYER, D. (ca.1860): Verzeichnis von Erdbeben und vulkanischen Ausbrüchen besonders mit Bezug auf die Schweiz, Ms., Vadiana, St. Gallen.

Mayer-Rosa, D. and B. CADIOT (1979): A review of the 1356 Basel earthquake, Tectonophysics, 53, 325-333.

MECOS (1999): Macroseismic Earthquake Catalogue of Switzerland (on line: http://seismo.ethz.ch/products/catalogs/).

MedvedeV, S.V., W. Sponheuer and V. KARNIK (1965): Seismic Intensity Scale Version MSK 1964, Akad. Nauk SSSR, Geofiz. Com. (Moscow), pp. 10.

Meghraoui, M., B. Delouis, M. Ferry, D. Giardini, P. Huggenberger, I. Spottke, and M. Granet (2001), Active Normal Faulting in the Rhine Graben and Paleoseismic Identification of the 1356, $I_{o}=$ IX-X, Basle Earthquake (Central Europe), Science, 293 (5537), 2070-2073.

Montandon, F. (1942): Les séismes de forte intensité en Suisse, Rev. pour l'Etude des Calamités, Geneve, fascicules 18-21.

Mueller, E. (1380): Yearbook of the Town of Zürich, in L. ETTMUELLER, Zürich, 1844, p. 88; in W. WACKERNAGEL, 1856.

PAVONI, N. (1977): Erdbeben im Gebiet der Schweiz, Eclog. Geol. Helv. 70 (2), 351-370.

RÜTTENER, E. (1995): Earthquake Hazard Evaluation for Switzerland, Materiaux pour la Géologie de la Suisse, Geophysique, 29 (Commission Suisse de Géophysique, Zürich).

SAEgesser, R. and D. MAYER-RosA (1978): Erdbebenge- 
fährdung in der Schweiz, Schweizerische Bauzeitung, Heft 7, pp. 16.

SCAT (1975): Swiss Earthquake Catalogue, Swiss Seismological Service (ETH, Zürich), computer file.

SCHEUCHZER, J.J. (1716-1718): Historische Beschreibung aller Erdbidmen, welche in dem Schweizerlande von Zeit zu Zeit gespürt worden, in Beschreibung der Natur-Historie des Schweizerlandes, 3 parts.

SCHIBLER, R. (2000): Makroseismische Untersuchung der Erdbeben von 1946 im Mittelwallis, Diploma Thesis, (Inst. of Geophysics, ETH, Zürich), pp. 76.

SED (1913-1964): Seismologische Jahresberichte des Schweiz. Erdbebendienstes, Archives Swiss Seismological Service (ETH, Zürich).

SENn VON Münsingen, JoH. (1362): Codex diplomaticus Urstisii, Public Library in Basel, in W. WACKERNAGEL, 1856.

SiEBERG, A. (1940): Beiträge zum Erdbebenkatalog Deutschlands und angrenzender Gebiete für die Jahre 58 bis 1799, Mitt. Deutsch. Reichs-Erdbebendienst, H. 2 (Jena), pp. 112.
SPONHEUER W. (1952): Erdbebenkatalog Deutschlands und angrenzender Gebiete für die Jahre 1800 bis 1899 (Academie-Verlag, Berlin), pp. 195.

VolgeR, G.H.O. (1857, 1858): Untersuchungen über das Phänomen der Erdbeben in der Schweiz, Justus Perthes, Gotha, vol. I, pp. 367; vol. II, pp. 522.

WACKeRnAGel, W. (1856): Das Erdbeben von 1356, in Basel im 14. Jahrhundert, Basler Historische Gesellschaft, H. Georg's Verlag, 211-253.

WANNER, E. (1932): Erdbebenkatalog der Schweiz für die Jahre 1856-1879, Jahresberichte des Schweizerischen Erdbebendienstes 1932, 16-21.

WeCHSLER, E. (1987): Das Erdbeben von Basel 1356, Teil 1. Historische und kunsthistorische Aspekte, SED Publication Series (ETH, Zürich), 102.

Wössner, J. (2001): Revision of the Macroseismic Catalogue and Database for Switzerland in the Time Period 1879 to 1963, Swiss Seismological Service, Zürich, Internal Report. 